\title{
Analysis of Mathematics Students Ability in Learning Metacognitive Strategy Type Ideal (Identify, Define, Explore, Act, Look)
}

\author{
Hasbullah $^{a}$ \& Basuki Wibawa ${ }^{b}$ \\ aMathematics education, University of Indraprasta PGRI, INDONESIA \\ bEducational Technology, Jakarta State University, INDONESIA
}

\begin{abstract}
This study aims to analyze the problem solving skills of grade VII students in learning metacognitive strategy type IDEAL. The method used is qualitative research with descriptive approach to analyze the result of mathematics problem solving test with indicator 1 ) understand and represent problem, 2) choose or plan the solution, 3) solve the problem according to plan, and 4) re-check the result. This research was conducted in Madrasah Tsanawiyah Wanasaba sub-district. The time of the research was conducted in the even semester of the 2015/2016 school year, starting from February 2016 until March 2016. The results showed that $6.41 \%$ of students were able to plan the solution, $11.54 \%$ of the students were able to solve the problem as planned and $82.05 \%$ of students were able to re-examine the results obtained. Based on these results, IDEAL type metacognitive learning strategy can improve students' math problem solving skills.
\end{abstract}

KEYWORDS

Problem Solving Abilities, Mathematics, Metacognitive Learning Strategy, IDEAL
ARTICLE HISTORY

Received 10 August 2017 Revised 28 September 2017 Accepted 15 November 2017

\section{Introduction}

Mathematics section of the science studied ranging from elementary, junior high, high school / vocational school even in Higher Education. Mathematics has a characteristic, that has an abstract object. The abstract nature of mathematics makes mathematical material difficult for students to comprehend. This makes it a challenge for students to always learn it. Mathematics learning in schools is expected to be a fun activity, so that the learning of mathematics affects the realization of the objective of learning mathematics in accordance with the standards.

\section{CORRESPONDENCE Hasbullah $\square$ hasbule@gmail.com}

(c) 2017 Hasbullah \& B. Wibawa.

Open Access terms of the Creative Commons Attribution 4.0 International License apply. The license permits unrestricted use, distribution, and reproduction in any medium, on the condition that users give exact credit to the original author(s) and the source, provide a link to the Creative Commons license, and indicate if they made any changes. (http://creativecommons.org/licenses/by/4.0/) 
The standard of mathematics learning according to National Council of Teachers of Mathematics (2000: 29) are: (1) learning to solve problems (problem solving); (2) learning to reason (reasoning and proof); (3) learning to communicate (communication); (4) learning to connect ideas (connections); (5) learning to represent (representaion).

To achieve the learning objectives of mathematics according to these standards, learning needs attention. Therefore, it is necessary to anticipate early steps so that students interested in mathematics subjects, which will have implications on the optimal learning outcomes. This will be created if students do not experience obstacles or difficulties in learning mathematics.

In fact, mathematics learning in most schools is still not up to standard. The result of observation and interview with teacher of VII grade Madrasah Tsanawiyah of Wanasaba subdistrict of East Lombok, students' ability to solve the problem is still low. The low ability of problem solving of student math is seen from: 1) when faced with a story problem, students are not used to write down what is known and what is asked from the problem before solving it, so that students are often wrong in interpreting the intention of the problem, 2) the lack of student accuracy in the mention of mathematical symbols or notations, for example that most students still can not distinguish between symbols for set slices with symbols for aggregates, 3) the student's hesitancy to communicate mathematical ideas such as solving story problems.

On the other hand, all students in madrasah tsanawiyah have never participated in mathematics olympiads either at the sub-district level or at the district level. This is because the interest in learning mathematics is very minimal and students only focus on the field of Religion both Fiqh, Qu'ran Hadith, and Arabic. The ability to solve problems is very important to be developed in the learning of mathematics. Ability to solve mathematical problems will be obtained by students well if the learning occurs communication between teachers and students or between students so that students have the opportunity to better understand a mathematical concept of the sharing of ideas (sharing ideas). Schoenfeld in Henningsen \& Stein (1997: 524), positioned the mathematical aspect as an activity for searching and exploring patterns for understanding mathematical formulas and relating hub connections; use existing resources effectively and appropriately to simulate and solve problems. Therefore, it is appropriate if problem solving gets special attention in learning mathematics in school.

To develop math problem solving abilities in Madrasah Tsanawiyah, Wanasaba sub-district of Lombok Timur, it is necessary to design a learning that familiarizes students to construct their own knowledge that can support and guide students on math problem solving skills, so that students better understand the concepts taught and able to communicate ideas or ideas mathematics. Learning strategies that can be designed is to apply effective learning strategies. Effective learning strategies that can be applied to foster math problem solving skills is one of them is learning with Metacognitive strategy. Metacognitive strategy is a form of ability to look at the students themselves so that what is done can be controlled optimally.

In many countries including Asia, for example the State of Turkey in improving students' mathematical problems using metacognitive strategies. 
This is in accordance with Ozsoy (2009: 3), that metacognitive strategies have a positive impact on students in improving problem-solving skills. Through metacognitive learning strategies, mathematical problem solving on students can be directed to develop students' skills, among others, to build new mathematical knowledge, solve problems in various contexts related to mathematics, apply various strategies as needed, and reflect on mathematical problem-solving process. All these abilities can be obtained when students are accustomed to carrying out problem-solving according to appropriate procedures, so the scope of benefits gained is not only tied to one solved problem, but also touched on many other issues and includes a broader aspect of mathematical knowledge. Metacognitive strategies in which there is a process of thinking in problem solving is important and gets the attention of educators specially to help students to develop their ability to solve problems. This is in line with the main purpose of teaching problem solving in mathematics is not only to equip students with a set of skills or processes, but rather to enable students to think about what they think.

\section{Literature Review}

One of the lessons students receive in school is math. Understanding mathematics many proposed by educational experts with a different point of view with each other. As stated by Idris (2006: 4) says that "mathematics is associated with structure, arrangement, precision, logic and problem." It is further said that "the term mathematics brings on the image of the use symbol, addition, subtraction, multiplication, division, problem solving and the memorization of rule. "The point is that mathematics is often associated with structure, arrangement, precision, logic and even mathematical problems related to the use of symbols, addition, subtraction, multiplication, division, problem solving and memorization of formulas.

According to Franklin (2014: 1), "Mathematics is a science of the real world, just as much as biology or sociology are. "Peirce (2010: 1)," Mathematics is distinguished from other practices (such as poetry) that "frame hypotheses" by its exclusive concern with deducing the consequences of its hypotheses. "From some of the above opinions it can be concluded that mathematics is the structure, arrangement, precision, logic and even mathematical problems associated with the use of symbols, additions, subtraction, multiplication, division, problem solving. Mathematicians formulate their concepts of problem solving. According to Beetlestone (1998: 17), problem solving or problem solving provides an opportunity for students to use their imagination, try to realize their ideas, and think about possibilities. Nasution in kesumawati (2014: 2) argued that "problem solving can be viewed as a process whereby students find a combination of previously learned rules that they use to solve new problems".

Furthermore, Surya (2015: 145) states "Problem Solving is the cognitive strategies necessary to carry out the life tasks that must be faced in everyday life with a range of difficulties ranging from the simplest to the most complex". the three definitions above there are several things in relation to problem solving that is optimizing imagination, new ideas, ability to think and combine new rules, because the problem solver must collect sub-goals to achieve the 
ultimate goal. Problem solving is part of a very important mathematical curriculum. the problem-solving learning process, enabling students to gain experience, using their knowledge and skills to apply to non-routine problem solving that encompasses open issues ie problems with various solutions.

Woolfolk (2007: 295) defines "problem solving is usually defined as formulating new answers." Solving problems formulate new answers, beyond the preceding rules to achieve goals. Mayer and Wittrock in Gredler (2009: 251), "problem solving as intellectual ability," aimed at general improvement in intellectual abilities". According to Wena (2009: 52), "problem solving as a process to find a combination of a number of rules that can be applied in an effort to cope with the new situation. Problem solving is not merely a form of being able to apply rules that have been mastered through past learning activities, but more than that, is the process of getting a set of rules at a higher level".

Problem solving on students has goals ranging from remediation to critical thinking to the development of creativity. Wangkat and Oreovocz in wena (2009: 53), classifies five levels of taxonomy of problem solving: routine, diagnostic, strategy, interpretation, and generalization. Regular taxonomy is routine or algorithmic action performed without making a decision. For example, some mathematical operations such as quadratic equations, integral operations, including routine problems. Diagnostic taxonomy is the selection of a procedure or the right way on a regular basis. For example, some formulas are used in determining the stress of a beam, and diagnostics is choosing the right procedure to solve the problem.

Taxonomy strategy is routine selection of procedures to solve a problem. Strategy is part of the analytical and evaluation phase in Bloom's taxonomy. Taxonomy interpretation is a real problem-solving activity, because it involves activities to reduce the real problem, so it can be solved. Taxonomy generalization is the development of routine procedures to solve new problems. According to Nickle in Rani (2008: 14), explains that there are five stages of mathematical problem solving namely identification the problem question, recognising the operation to use, writing a mathematical sentence to explain the relationship between measurement (writing the mathematical sentence to express a relationship between given measure), find the numbers provided to make the correct sentence (examine the formula given, which will make the sentence true), examine the formula through the evaluation of the formula and mark the answer (checking the equation by evaluating the equation and labeliing answer). The problem-solving stage, especially the most well-known mathematical problem is the Polya problem solving stage quoted by Rani (2008: 17-18), mentions that there are four stages of problem solving: 1) understanding and representing the problem, 2) choosing or planning solving problems as planned, and 4) reviewing the results obtained.

Based on the above concepts, it can be concluded that problem solving ability is the ability to find a combination of a number of rules that can be applied in an effort to overcome the new situation through the stages of understanding and representing the problem, choosing or planning the solution, solving the problem as planned, and re-examining the results obtained. 
IDEAL Metacognitive Learning Strategy Metacognitive is a term first introduced by Flavell in 1976. According to Anderson and Krathwohl (2001: 3), states that metacognitive in the classification (taxonomy) of knowledge, incorporates metacognitive as one kind of knowledge and puts metacognitive at the highest order above knowledge factual, conceptual, and procedural. Metacognitive includes high-level thinking that involves active control of the cognitive processes involved in learning activities. This is in accordance with the statement of Petroselli (2008: 64), that "Metacognition refer to higher order thinking that involve active control over the thinking processes involved in learning. It goes on to say that the basis of metacognitive is activities such as planning on how to approach a given task during learning, monitoring understanding and evaluating progress of task completion.

From the above concept can be said that metacognitive is the level of thinking ability involves active control of the cognitive process from planning, monitoring and evaluation. planning on how to approach learning, monitoring the understanding and evaluating the progress of learning.

Flavell in Hardy and Mawer (2003: 38), states that, "They re- "While Woolfolk (2007: 64), suggests that metacognition is the awareness of the process of thinking and when that process occurs. From the various definitions put forward by some experts above can be concluded that metacognitive is the level of thinking ability involves active control on the cognitive process of a person in learning that starts from planning, monitoring and evaluating the learning. While metacognitive strategies relate to ways to raise awareness about the process of thinking and learning that takes place. When consciousness exists, one can control his or her mind. Students can use metacognitive strategies in learning include the following three stages: designing what they want to learn; monitor self-development in learning; and assess what is learned. Metacognitive strategies can be used for any study of any field of study. It is important to direct students to be able to consciously control the process of thinking and learning by students.

Chamot in Juan and Flor (2006: 80), states that, "a task in progress and evaluate the success of a task after its completion. "According to O'malley and the chamot in Graham and Santos (2015: 28), states that" metacognitive strategies as' higher order executive skill that may entail planning for, monitoring, or evaluation of the success of a learning activity. "Meanwhile, according to Weiner (2003: 81), states that" metacognitive strategies as activities for monitoring cognitive processes. The above concepts can conclude that metacognitive strategies are the cognitive processes associated with the regulation and management of the learning process, and include strategies used in task planning, task monitoring and evaluating the success of student tasks after completion.

AeU in Kleden, Kusumah, and Sumarno (2015: 57) states that metacognitive learning strategies can be done by strategies: IDEAL (Identify, Define, Explore, Act, Look). IDEAL learning strategy was introduced by Bransford as a learning strategy used to assist students in metacognitive processes especially in improving thinking ability and problem solving. IDEAL 
stands for I-Identify problem, D-Define goal, E-Explore possible strategies, Aanticipate outcomes and act, L-look back and learn. According to Nickerson in Phillipson and Lam (2011: 141), states that "IDEAL refers to the steps that lead to problem solving and creativity, including identifying the problem, defining and representing the problem, exploring possible strategies, acting on the strategies and loking back and evaluating, "whereas according to Chidsey and Bickford (2016: 215), states that" IDEAL define a problem as the diffrence between what is expected and what happenating. The problem is not inherent to single person, but that a problem exists and needs to be addressed " From the above concepts it can be concluded that the DEAL strategy is a step that leads to problem solving and creativity, including identifying problems, defining and representing problems, exploring possible stsrategies, working on strategy and loking back and evaluating.

IDEAL is designed to help identify and understand the different parts of a problem solving, each letter representing an important component in the process of completion: (a) identify problems; (b) define the problem; (c) explore alternate intervention; (d) apply the selected intervention; and (e) look at the effects. As with other learning strategies, IDEAL learning strategies also have advantages, according to Elias and Colleagues in Wehmeyer (2007: 46): "a) to increase awareness of problem and to introduce the idea of problem solving, b) to encourage positive expectations for problem solving and divert attention from negative or preooccupying thoughts, c) to encourage persistence against emotional stress and diffcul situation, d) to facilitate a positive emotional state.

\section{Methodology}

This research is reviewed from its kind including qualitative research. Qualitative research method is a research method used to examine the condition of natural objects. The approach in this research is descriptive approach that aims to describe what is currently applicable. Bogdan and Taylor (Rofiqoh, 2015: 44) Qualitative approach is a research procedure that produces data in the form of written or oral words of people and behavior that can be observed. This research is an attempt to describe, record, analyze and interpret the conditions that occur. The problem described in this research is students' math problem solving abilities. To describe the ability to perform the test by giving the test that is by analyzing the results of math problem solving test with the indicators 1) understand and represent the problem, 2) choose or plan the solution, 3) solve the problem according to plan, and 4) re-examine the results obtained. This research was conducted in Madrasah Tsanawiyah Wanasaba sub-district. The time of the research was conducted in the even semester of the 2015/2016 school year. The sample of the study was conducted randomly by choosing the school as a place of study. The research sample was conducted in Madrasah Tsanawiyah Tarbiyatul Islam Azizah NW Wanasaba class VII. Implementation of the study tailored to the lesson schedule at the school where the study.

\section{Results}

First of all before the research is done, empirical validity is done. The empirical validity of an instrument or test is determined on the basis of the measured data of the instrument concerned through actual tests or peg measures. Because the instrument form has more than two responses, the Validity of the item is calculated using Product Moment Correlation (Selvan: 
$2010,160)$. The criterion of the test item is valid if the $r_{\text {count }}$ is greater than the rtable (Product Moment table) at the 0.05 significance level with $\mathrm{n}=$ the number of test participants. An item can be said to be valid if it has ( $r$ ) significant at the chosen level of significance.

The result of the instrument test of mathematical problem solving ability using Product Moment Correlation, from 10 items of valid declared 9 item and not valid is only one problem. Invalid items are dropped and not used in the test instrument test list. Test the reliability of the test instrument of mathematical problem-solving ability has a scale shape, then the calculation of reliability coefficient using Alpha Cronbach "(Huisman and Tight: 2015, 123) .The number of questions calculated level of reliability is 9 questions after.Results of reliability coefficients ability of problem solving math ( rii) $=0.75$ Based on these results, it can be concluded that the instrument of problem solving ability of mathematics has high reliability or in other words the instrument can be enriched, this is in accordance with opinion Hartas (2010: 74), "the assumption is that if the items in both tests measure that same concept, they will be strongly related, with a correlation (r) over 0.7. " The results of the test The ability of problem solving of mathematics students who were given learning with IDEAL learning strategy (Identify, Define, Explore, Act and Look) obtained the following results: the number of respondents 26 people, the minimum score 52 , the maximum score 82 , the range of empirical score obtained is 87-52 = 35, and theoretical range 0-90. Furthermore, the data is presented in frequency distribution table with number of class 6 , interval class 6 width, average score is 68,00 , mode 71,5 , median 68,3 and standard deviation 8,54. The following table presents the distribution of Frequency Score Ability Problem Solving Mathematics Student Group who was given IDEAL Learning Strategy.

The score of problem solving ability of mathematics of students who were studied with IDEAL learning strategy (Identify, Define, Explore, Act and Look), showed that there were $9(34,62 \%)$ students below interval class containing average score, $5(19.23 \%)$ students were in the interval class containing the average score and $12(46.15 \%)$ of the students were above the interval class containing the average score. Based on the above data it can be said that students who have scores above the average score more than students who score below average.

To clarify the data of students' mathematical problem-solving skills that are given learning by IDEAL learning strategy (Identify, Define, Explore, Act and Look), then the following is presented visually with the following histogram view. 


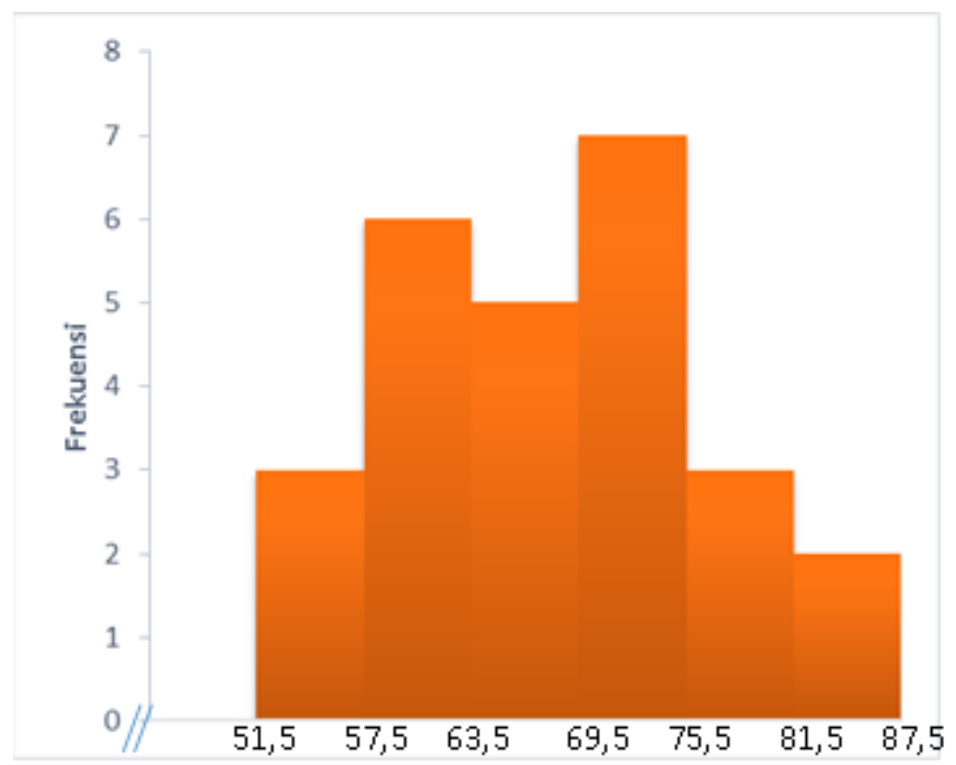

Figure 1 Histogram Score Student Group Ability Given IDEAL learning strategy

While the analysis of mathematics problem solving skills with indicators 1) understand and represent problems, 2) plan the solution, 3) solve the problem according to plan, and 4) review again, presented in the table below:

\begin{tabular}{|c|c|c|c|c|c|c|c|c|c|}
\hline \multirow{3}{*}{ No } & \multirow{3}{*}{$\begin{array}{l}\text { Item } \\
\text { Problem }\end{array}$} & \multicolumn{8}{|c|}{ Mathematical Problem Solving Indicator } \\
\hline & & \multicolumn{2}{|c|}{$\begin{array}{l}\text { understand and } \\
\text { represent } \\
\text { problems }\end{array}$} & \multicolumn{2}{|c|}{$\begin{array}{l}\text { plan the } \\
\text { solution }\end{array}$} & \multicolumn{2}{|c|}{$\begin{array}{l}\text { solve the problem } \\
\text { according to plan }\end{array}$} & \multicolumn{2}{|c|}{ review again } \\
\hline & & $\mathrm{Fn}$ & $\%$ & Fn & $\%$ & Fn & $\%$ & Fn & $\%$ \\
\hline 1 & Problem 1 & 0 & 0 & 4 & 15,38 & 6 & 23,08 & 16 & 61,54 \\
\hline 2 & Problem 2 & 0 & 0 & 2 & 7,69 & 3 & 11,54 & 21 & 80,77 \\
\hline 3 & Problem 3 & 0 & 0 & 0 & 0 & 2 & 7,69 & 24 & 92,31 \\
\hline 4 & Problem 4 & 0 & 0 & 0 & 0 & 2 & 7,69 & 24 & 92,31 \\
\hline 5 & Problem 5 & 0 & 0 & 3 & 11,54 & 4 & 15,38 & 19 & 73,11 \\
\hline 6 & Problem 6 & 0 & 0 & 2 & 7,69 & 4 & 15,38 & 20 & 76,93 \\
\hline 7 & Problem 7 & 0 & 0 & 3 & 11,54 & 3 & 11,54 & 20 & 76,92 \\
\hline 8 & Problem 8 & 0 & 0 & 0 & 0 & 2 & 7,69 & 24 & 92,31 \\
\hline 9 & Problem 9 & 0 & 0 & 1 & 3,85 & 1 & 3,85 & 24 & 92,31 \\
\hline & Amount & 0 & 0 & 15 & 6,41 & 27 & 11,54 & 196 & 82,05 \\
\hline
\end{tabular}

Based on the above table it can be explained that on item about the number 1 (one) there are $15.38 \%$ of students who are able to solve the problem in the planning phase of the problem, $23.08 \%$ of students who only able to solve the problem in the stage of solving the problem according to plan and $61.54 \%$ of students who are able at the re-check stage. on item number 2 (two) there are 
$7.69 \%$ of students who are able to solve the problem in the planning phase of the problem, $11.54 \%$ of students who are only able to solve the problem in the problem-solving stage as planned and $80.77 \%$ students who are able to check back. on item number 3 (three) there are $7.69 \%$ of students who are only able to solve the problem in the stage of solving the problem as planned and $92.31 \%$ of students who are able to re-check stage. on item number 4 (four) there are $7.69 \%$ of students who are only able to solve the problem in the stage of solving the problem as planned and $92.31 \%$ students who are able to re-check stage.

on item number 5 (five) there are $11.54 \%$ of students who are able to solve the problem in the planning phase of the problem, $15.38 \%$ of students who only able to solve the problem in the stage of solving the problem as planned and $73.11 \%$ of students who are able to check back. on item number 6 (six) there are $7.69 \%$ of students who are able to solve the problem in the planning phase of the problem, $11.54 \%$ of students who are only able to solve the problem in the problem-solving stage as planned and $76.93 \%$ of students who are able to check back. on item number 7 (seven) there are $11.54 \%$ of students who are able to solve the problem in the planning phase of the problem, $11.54 \%$ of students who are only able to solve the problem in the stage of solving the problem as planned and $76.92 \%$ of students who are able to check back. on item number 8 (eight) there are $7.69 \%$ of students who are only able to solve the problem in the stage of solving the problem as planned and $92.31 \%$ of students who are able to recheck stage. and on item number 9 (nine) there are $3.85 \%$ of students who are able to solve the problem in the planning phase of the problem, $3.85 \%$ of students who are only able to solve the problem in the stage of solving the problem as planned and $92.31 \%$ of students who are able at the stage check again.

\section{Discussion}

The measurement indicators of mathematical problem solving ability consists of four stages: 1) understanding and representing the problem, 2) selecting or planning the solution, 3) resolving the problem as planned, and 4) checking the results obtained. The results showed that $6.41 \%$ of students were able to plan solutions, $11.54 \%$ of students were able to solve the problem according to plan and $82.05 \%$ of students were able to check the results obtained. Based on these results, IDEAL type metacognitive learning strategy can improve students' math problem solving skills. Nickerson in Phillipson and Lam (2011: 141), states that "IDEAL to the step that leads to problem solving and creativity, including identifying the problem, defining and representing the problem, exploring possible strategies, acting on the strategies and looking back and evaluating, "On the other hand, based on syntax owned by IDEAL that starts from Identifying (identify) the problem is deliberately trying to identify the problem and make it as an opportunity to do something creative. The ability to identify the existence of a problem is an important characteristic to support the successful resolution of the problem. Then define the goal of the students developing an understanding of the problems identified and trying to define the objectives because of the problems that depend on how the students define the goals, and this has an important effect on the type of answers to be addressed. Differences in goal setting can be very powerful causes for students' ability to 
understand problems, think and solve problems. Explore possible strategies and evaluate the likelihood of such strategies in accordance with the stated objectives. anticipate (anticipate) results and act (Act), when a strategy is chosen, it anticipates the likely outcome and then acts on the chosen strategy. The final step of IDEAL is to look (Look) the real impact of the strategy used and learn from the experience gained. Seeing and learning needs to be done because after getting results, many forget to look back and learn from the problem solving that has been done. Not all problems can be solved in one step of the work.

The results of research by Rahayu and Kartono (2014: 1315), concluded that the mathematical disposition component is directly and indirectly affected to the problem solving ability in PMRI based on IDEAL Problem Solve. Another study conducted by Eko Andy Purnomo and Venissa Dian Mawarsari (2014: 90), illustrates that to improve mathematical power is the application of IDEAL learning model. The results of the research (a) produced textbooks of equations of equations, opportunities, trigonometry, derivatives and good linear programs; (b) implementation of the IDEAL learning model can improve the ability to solve mathematical problems.

IDEAL learning strategy, students are given the opportunity to seek and solve a problem of their own. IDEAL learning strategy is a specific strategy of metacognitive approach that promotes effectiveness and efficiency in thinking and problem solving. Teachers facilitate effective thinking and problem solving. Effective problem solving should begin with the identification of potential difficulties which will then be followed by problem identification. Students take action on their own solutions. Generally, students who have sufficient competence will plan for their thought processes, through reflection and openminded in finding solutions. Finally, after finding the solution, note the student on what it takes to get the optimal solution.

\section{Conclusion}

It can be concluded that IDEAL learning strategy that is: (1) student is more active in asking, this is proved by communication between student and teacher. Communication is built on student responses in activities such as thinking to solve problems; (2) the effectiveness of learning with the IDEAL strategy is influenced by guidance to the principal students how to apply the learning steps in their investigation.

\section{Recommendations}

Based on the conclusion of the research that has been put forward earlier, then the teacher in learning mathematics related to solving the problems of mathematics hendakanya using metacognitive learning strategies IDEAL (Identify, Define, Explore, Act and Look), in addition to using metacognitive learning strategies that have been used.

\section{Disclosure statement}

No potential conflict of interest was reported by the authors.

\section{Notes on contributors}


Hasbullah - Mathematics education, University of Indraprasta PGRI, INDONESIA

Basuki Wibawa- Educational Technology, Jakarta State University, INDONESIA

\section{References}

Anderson, Rin W. \& David R. K. (2001). A Taxonomy for Learning; teaching and Assessing: A revision of Bloom's Taxonomy of Education Objectives. New York: Addison Wesley Lonman Inc.

Beetlestone, F. (1998). Creative Children, Imaginative Teaching. Philadelphia: Marston Book Services Limites.

Chidsey, Rachel B. \& Rebekah B. (2016). Practical Handbook of Multi-Tiered Systems of Support: Building Academic and Behavior Success in Schools. Ney York: The Guilford Press.

Franklin, J. (2014). An Aristotelian Realist Philosophy of Mathematics: Mathematics as Science of Quantity and Structure. New York: Palgrave Macmillan.

Graham, S. \& Denise S. (2015). Strategies for Secondary Listening: Current Scenarios and Improved Pedagogy. Chennai: Palgrave Macmilan.

Gredler, Margaret E. (2009). Learning and Instruction: Theory into Practice Sixth Edition. London, Pearson.

Hardy, Colin A. \& Mick M. (2003). Learning and Teaching in Physical Education. London: Falmer Press.

Hartas, D. (2010). Educatinal Research and Inquiry: Qualitative and Quatitative Approaches. London: Continum International Publishing Group.

Henningsen, M. \& M. K. Stein. (1997). "Mathematical tasks and student cognition: Classroom-based factors that support and inhibit high-level mathematical thinking and reasoning," Journal for Research in Mathematics Education, Vol. 28 (5), h. 524.

Huisman, J. \& Malcolm T. (2015). Theory and Methods in Higher Education Research. Bingley: Emerald Group Publishing Limited.

Idris, N. (2006). Teaching and Learning of Mathematics: Making Sense and Developing Cognitive Abilities. Kuala Lumpur: Maziza.

Juan, Ester U. \& Alicia Martinez F. (2006). Current Trend in The Delopment and Teaching of the Four Language Skills. New York: ANSI.

Kesumawai, N. (2014). "Improving Mathematical Problem Solving Ability of Junior High School Students Mellaui Approach of Indonesian Realistic Mathematics Education (PMRI)," Jurnal Pendidikan Matematika, Vol. 8 (2), h. 2.

Kleden, Maria Agustina, Yaya S. Kusumah, and Utari S. (2015). "The Analysis of Enhancement of Mathematical Education Competency through Metacognitive Learning," International Journal of Education and Research, Vol. 3 (9).

NCTM. (2000). Principles and Standard for School Mathematics. United States of America: NCTM.

Ozsoy, G. (2009). "The Effects of Metacognitive Strategy Training on Mathematical Problem Solving Achievement". International Electronic Journal of Elementary Education, Vol.1 (2). h. 3.

Peirce, Charles S. (2010). Philosophy of Mathematics: Selescted Writings. Indiana: Indiana University Press, .

Petroselli, Calvin L. (2010). Science Education Issues and Developments. New York: Nova Science Publishers, Inc.

Phillipson, Shane N. \& Bick-har L. (2011). Learning Teaching in the Chinese Classroom: Responding to Individual Needs. Hong Kong: Hongkong University Press. 
Purnomo, Eko A. \& Venissa D. (2014). "Improving Problem-Solving Ability through Ideal Problem Solving Learning Model Based on Project Based Learning", JKPM, VOL. 1 (1).

Rahayu, R. \& Kartono. The Effect of Mathematical Disposition to Problem Solving Ability Based On IDEAL Problem Solver. International Journal of Science and Research (IJSR). VOL. 3 (10), h. 1315

Rani, T. S. (2008). Teaching of Mathematics Delhi: Navin Shahdara.

Selvan, A. (2010). Human Rights Education: Moderan Approaches and Strategies. New Delhi: Concept.

Surya, M. (2015). Cognitive Strategies in Learning Process. Bandung: Alfabeta.

Wehmeyer, Michael L. (2007). Promoting Self-determination in Students with Developmental Disabilities. New York: The Guilford Press.

Weiner, Irving B. (2003). Hanbook of Psychology: Educational Psychology Volume 7, New Jersew: John Wiley and Sons, Inc.

Wena, M. (2009). Contemporary Innovative Learning Strategy: An Operational Conceptual Review. Jakarta: Earth Script.

Woolfolk, A. (2007). Educational Psychology Tenth Edition. Boston: Pearson.

Facer, K. (2006). Learning with handheld technologies: A handbook from Futurelab. Bristol, UK: Futurelab. http://www.futurelab.org.uk/research.

Federal Republic of Nigeria. (2004). National Policy on Education (Revised) NERC.

Glennie, J., Harley, K., Butcher, N. \& Van Wyk, T. ( 2012). Open Educational Resources and change in Higher Education: Reflections from practice. British Colombia: Vancouver.

Hartnell-Young, E. \& Heym, N. (2008). How mobile phones help learning in secondary schools? BECTA.http://research.becta.org.uk/index.php?catcode=_re_rp_02\&rid=15482\&section=rh, [17 November 2013].

Howie, S. J. (2003). Language and other background factors affecting secondary pupils' performance in Mathematics in South Africa. African Journal of research in Mathematics, Science and Technology Education, 7, 1-20.

http://www.scit.wlv.ac.uk/brendan/mLearn2008.pdf,[30 November 2013].

Johnson, B. \& Christensen, L. (2012). Educational Research. Quantitative, qualitative, and mixed approaches, 4th ed. Thousand Oaks, CA: Sage Publications.

Kadirire, J. (2007). Instant messaging for creating interactive and collaboration m-Learning environments. International Review of Research in Open and Distance Learning, 2(8),1-14.

Kahn, M. J. (1994). Science and Mathematics education in the formal system: Science and technology education and training for economic development. Johannesburg: Centre for Education Policy Development.

Kalloo, V. \& Mohan, P. (2012). MobileMath: an innovative solution to the problem of poor Mathematics performance in the Caribbean. Caribbean Teaching Scholar, 2(1), 5-18.

Khuzwayo, B., (2005). A history of Mathematics education research in South Africa: The apartheid years. Researching Mathematics education in South Africa: Perspectives, practices and possibilities, 234, 286p.

Kinsley, J. (2002). A four stage model of mathematical learning. The Mathematics Educator Journal, $12(1), 11-16$.

Koller, O., Baumert, J. \& Schnabel, K. (2001). Does Interest Matter? The Relationship Between Academic Interest and Achievement in Mathematics. Journal for Research in Mathematics Education, 32 (5), 448-470.

Kriek, J. \& Grayson, D. (2009). A Holistic Professional Development model for South African Physical Science teachers. South African Journal of Education, 29, 185-203. 
Kumar, A., Tewari, A., Shroff, G., Chittamuru, D., Kam, M. \& Canny, J. (2010). An Exploratory Study of Unsupervised Mobile Learning in Rural India. In CHI 2010, 10-15 April 2010, Atlanta, Georgia, USA.

Liebenberg, J. \& Conway-Smith. (2008). Mobile Mathematics-lessons learned. In Proceedings of the mLearn 2008 Conference, The Bridge From Text To Context, 7-10 October 2008, 346p.UK.Ironbridge Gorge: Shropshire.

Lubega, J., McCrindle, R., Williams, S., Armitage, U. \& Clements, I. (2004). Uses of mobile phones in higher education. In Cantoni and McLaughlin (eds) Proceedings of EDMEDIA 2004. Switzerland: Lugano.

Makgato M. \& Mji, A. (2006). Factors associated with high school learners' performance: A spotlight on mathematics and physical science. South African Journal of Education, 26(2), 253-266.

Manoucherhri, A. (1999). Computers and school mathematics reform: Implications for mathematics teacher education. Journal of Computers in Mathematics and Science Teaching, 18(1), 31-48.

Maree, K., (2007). First steps in Research. 1st ed. Pretoria: Van Schaik publishers.

McMillan, J.H. \& Schumacher, S. (2010). Research in education: Evidence-based inquiry. 7th ed. New York: Pearson.

MoMath, (2010). Mobile learning for Mathematics: Nokia project in South Africa Symbian tweet, http://www.symbiantweet.com/mobile-learning-for-Mathematics in South Africa, [20 February 2014]

Mulhern, F. \& Rae, G. (1998). Development of shortened form of the Fennema-Sherman mathematics attitude scales. Educational and Psychological Measurement, 41, 551-557.

Nagaki, T., Kobayashi, Y. \& Nakagawa, H. (2004). Attitude survey for pupils about using cellular phones in Classrooms. In Cantoni and McLaughlin (eds.) Proceedings of ED-MEDIA 2004, Switzerland: Lugano.

Naismith, L. \& Corlett, D. (2006). Reflections on success: A retrospective of the mLearn conference series 2002-2005. Paper presented at mLearn 2006 - Across generations and cultures. Canada. Banff. http://hal.archivesouvertes.fr/docs/00/19/73/66/PDF/Naismith-Corlett2006.pdf.

Ndafenongo, G. (2011). An investigation into how cell phones can be used in the teaching of Mathematics using Vitalmaths video clips: a case study of 2 schools in Grahamstown, South Africa. Thesis, Degree of Master of Education, Rhodes University (Faculty of Education), Grahamstown, South Africa.

Ornstein, A.C. (1990). Strategies for effective teaching. New York: McGraw-Hill Inc.

Peker, M. (2005).The relationship between learning styles and Mathematics achievement students' acquiring primary Mathematics teacher education. Eurasian Journal of Educational Research, 5 (21), 200-210.

Project K-Nect. (2008). http://www.projectknect.org/Project\%20K-Nect/Home.html http://www.cxc.org/examinations/exam-results-reports. [30 May 2014].

Retrieved from http://mlearningafrica.net/category/projects/

Saha, S. (2007). A study of Gender Attitude to Mathematics. Cognitive Style and Achievement in Mathematics. Experiments in Education 35(6).

Sharples, M. (2003). Disruptive devices: mobile technology for conversational learning. International Journal of Continuing Engineering Education and Lifelong Learning, 1(5\& 6), 504-520.

Stead, G. (2005). Moving mobile into the mainstream. In Proceedings of mLearn: Mobile technology: The future of learning in your hands, 25-28 October 2005, South Africa, Cape Town, London: WLE Centre.

Sweeting, K. (2011). Early Years Teachers' Attitudes in Mathematics. M.Ed Thesis. Queensland University of Technology. University of Haifa. http://construct.haifa.ac.il. 
Vahey, P. \& Crawford, V. (2003). Learning with handhelds: Findings from classroom research. http://makingsens.stanford.edu/pubs/LearningFromHandhelds.pdf. [15 May 2014].

Vosloo, S. \& Botha, A. (2009). Mobile learning: South African examples. Paper presented at the Mobile Learning Institute Summit. Lusaka, Zambia. Retrieved from http://www.slideshare.net/stevevosloo/mobilelearning-south-african-examples.

Vosloo, S. (2007). MOBITM.

Vosloo, S. (2008). M4Girls. Retrieved from http://mlearningafrica.net/category/projects/

Vosloo, S. (2009). ImfundoYami/ImfundoYethu: Mobile learning for Mathematics. Retrieved from http://mlearningafrica.net/category/projects/

Wilson, P. (2008). Promoting positive attitudes. Retrieved November 10, 2015 from Electronic Resources Information Centre (ERIC) database (ERIC Document No EJ815090).

Xia, X., Lu, C. \& Wang, B. (2008). Research on Mathematics Instruction Experiment Based Problem Posing, Journal of Mathematics Education, 1(1),153-163.

Yerushalmy, M. \& Weizman, A. (2007). Math4Mobile mobile environments. The University of Haifa. http://www.math4mobile.com/[12 February 2014].

Yerushalmy, M. (2007). Math4Mobile mobile environments. The University of Haifa. http://www.math4mobile.com/ [12 February 2014] 